\title{
Field resistance of potato cultivars to foliar early blight and its relationship with foliage maturity and tuber skin types
}

\author{
Henrique S. S. Duarte¹, Laércio Zambolim ${ }^{1}$, Fabrício A. Rodrigues ${ }^{1}$, Pierce A. Paul ${ }^{2}$, Joaquim G. Pádua ${ }^{3}$, \\ José I. Ribeiro Júnior ${ }^{4}$, Antonio F. N. Júnior ${ }^{1}$ \& André W. C. Rosado ${ }^{1}$ \\ ${ }^{1}$ Departamento de Fitopatologia, Universidade Federal de Viçosa, 36570-900, Viçosa, MG, Brazil; ${ }^{2}$ Departament of Plant Pathology, \\ Ohio State University, 44691, Wooster, OH, USA; ${ }^{3}$ Empresa de Pesquisa Agropecuária de Minas Gerais (EPAMIG), 37550- \\ 000, Pouso Alegre, MG, Brazil; ${ }^{4}$ Departamento de Estatística, Universidade Federal de Viçosa, 36570-900, Viçosa, MG, Brazil
}

Author for correspondence: Laércio Zambolim, e-mail: zambolim@ufv.br

\begin{abstract}
Three field experiments were carried out to assess the level of resistance of several cultivars to early blight (EB) and to examine the association between host resistance and either foliage maturity or tuber skin types. A total of 26 cultivars were used in Exps. 1 and 2 , and 24 in Exp. 3. Plants were inoculated with isolates of Alternaria grandis at 31 days after planting. EB severity was quantified in each plot every seven days. The approach to determine the resistance levels of potato cultivars was based on multivariate analysis techniques. The tested cultivars responded as either resistant, moderately resistant, moderately susceptible or susceptible to EB. Most of the cultivars were classified as susceptible or moderately susceptible to EB. Resistant cultivars were mid-season, mid-late or late maturity. None of the susceptible cultivars were later maturity (mid-late or late maturity). In most cases, susceptible cultivars were earlier maturity (early or mid-early maturity). Most resistant cultivars had rough, mid-rough or smooth skin. None of the susceptible cultivars had rough skin. In most cases, susceptible or moderately susceptible cultivars had smooth skin. Obtaining potato cultivars that are resistant to this destructive disease will help reduce production costs and the need for costly fungicides.
\end{abstract}

Key words: Alternaria grandis, Solanum tuberosum, disease management, foliar disease, host resistance, tissue susceptibility.

\section{INTRODUCTION}

Potato (Solanum tuberosum L.) is cultivated in more than 100 countries and ranks fourth among the food crops produced worldwide. In 2012, global and Brazilian potato production was estimated at 364 and 3.7 million tons, respectively (FAO, 2014). In Brazil and other countries, potato yield is often limited by diseases. Early blight (EB) is considered one of the most important diseases of potato, especially during the rainy season (Reifschneider et al., 1984; Guenthner et al., 1999; Shuman \& Christ, 2005).

Based on morphological studies, Simmons (2000) reported that Alternaria tomatophila Simmons and $A$. solani Sorauer were the causal agents of EB in tomato and potato, respectively. However, Rodrigues et al. (2010) found that $A$. grandis Simmons and A. tomatophila, but not A. solani, were the causal agents of EB affecting potato and tomato plants, respectively, in several growing regions in Brazil. Based on our observations, EB symptoms caused by $A$. grandis are very similar to those caused by $A$. solan $i$ observed in others countries.

Present address: 'Universidade Federal do Paraná, 80060-000, Curitiba, PR, Brazil.
EB symptoms on leaves, stems and tubers are dark, elongated or circular necrotic lesions with concentric rings (Jones, 1991; Rotem, 1994) that are especially visible at advanced stages of maturity (Johnson \& Teng, 1990; Dita Rodriguez et al., 2006). Plant defoliation may occur due to severe EB, leading to a reduction in both yield and quality of tubers (Castro et al., 2000).

Potato EB epidemics may occur during the entire year in Brazil (Batista et al., 2006). Considering the short life cycle of the pathogen, several reproductive cycles may be completed during the growing season (Rotem, 1994). Most of the cultivars available to growers are susceptible to EB, and disease control is very difficult to achieve when both temperature and relative humidity are high (Adams \& Stevenson, 1990). Therefore, fungicide sprays have become the best control strategy for minimizing yield losses caused by EB. However, these sprays increase production costs, are harmful to the environment and can select for fungicide-resistant isolates of the pathogen.

Other EB control strategies must be developed for use in an integrated disease management program. The use of resistant cultivars appears to be the most adequate strategy for controlling EB, especially when combined with fungicide spray. In Brazil, potato breeders look for foliage maturity and tuber skin types in addition to yield 
potential, agronomic traits, physical characteristics and culinary attractiveness before releasing a potato cultivar to growers.

Potato resistance to EB appears to be associated with cultivar maturity, with the late-maturing cultivars tending to be more resistant than early-maturing cultivars (Douglas et al., 1972; Mendoza et al., 1986; Herriott et al., 1990; Pelletier \& Fry 1990; Zhang, 2004; Dita-Rodríguez et al., 2006). However, because EB occurs most often during senescence of the host tissues, some cultivars may appear resistant simply because they are late maturing (Herriott et al., 1990). Zhang (2004) evaluated the genetics of partial resistance to $\mathrm{EB}$ in potato and observed that quantitative trait loci for disease resistance had pleiotropic effects on foliage maturity or were closely linked to genes involved in foliage maturity. Zhang (2004) also reported that some early or mid-season maturing clones of potato showed a high level of resistance to EB.

Since the major potato cultivars available to Brazilian growers are still unclassified in terms of their resistance to $\mathrm{EB}$, the objectives of the study were (i) to assess the level of resistance of these cultivars to this important disease by evaluating several epidemiological variables using multivariate analysis techniques and (ii) to determine the association between host resistance and either foliage maturity or tuber skin types.

\section{MATERIAL AND METHODS}

\section{General aspects of the field experiments}

Three field experiments were carried out under different environmental conditions to study the resistance of potato cultivars to foliar EB. The experiments were performed in a randomized complete block design with three replications, and each treatment corresponded to one cultivar. Each plot consisted of two rows measuring $3.0 \mathrm{~m} \times 0.8 \mathrm{~m}$, with each cultivar having $15 \mathrm{stems} / \mathrm{m}^{2}$ and spaced $1.6 \mathrm{~m}$ apart. Plots were fertilized according to chemical soil analyses and sprinkle irrigated as needed to enhance EB development. Exp. 1 was carried out from June 13 to September 8, 2009 in an experimental field at the Universidade Federal de Viçosa $\left(20^{\circ} 44^{\prime} 44^{\prime \prime} \mathrm{S}\right.$, $42^{\circ} 50^{\prime} 59^{\prime \prime} \mathrm{W}, 661 \mathrm{~m}$ above sea level). Twenty-six potato cultivars of different origins, foliage maturities and skin types were used (Table 1). This experiment was repeated (Exp. 2) from April 14 to July 17, 2010 using the same 26 potato cultivars. An additional experiment (Exp. 3) was carried out at the same location from April 14 to July 17, 2010 to assess the EB resistance of another 24 potato cultivars of different origins, foliage maturities and skin types (Table 2).

Climate variables (precipitation; maximum, average and minimum relative humidity; maximum,

TABLE 1 - Origin, foliage maturity and skin type of the potato cultivars evaluated in experiments 1 and 2.

\begin{tabular}{|c|c|c|c|}
\hline Cultivar & Origin & Maturity $^{\mathrm{a}}$ & Skin type \\
\hline Ágata & Netherlands & Early & Smooth \\
\hline Aracy & Brazil & Late & Rough \\
\hline Asterix & Netherlands & Mid-late & Mid-rough \\
\hline Atlantic & EUA & Mid-season & Rough \\
\hline Baraka & Netherlands & Mid-late & Rough \\
\hline Baronesa & Brazil & Mid-season & Smooth \\
\hline BRS Ana & Brazil & Mid-late & Mid-rough \\
\hline Caesar & Netherlands & Mid-late & Smooth \\
\hline Catucha & Brazil & Mid-season & Smooth \\
\hline Chipie & France & Mid-season & Mid-rough \\
\hline Colorado & France & Mid-late & Rough \\
\hline Cupido & Netherlands & Mid-early & Smooth \\
\hline Éden & France & Mid-season & Smooth \\
\hline Elodie & France & Mid-early & Smooth \\
\hline Emeraude & France & Mid-early & Smooth \\
\hline Eole & France & Mid-early & Smooth \\
\hline Florice & France & Mid-early & Smooth \\
\hline Fontane & Netherlands & Mid-season & Smooth \\
\hline Gourmandine & France & Mid-season & Smooth \\
\hline Ibituaçu & Brazil & Late & Smooth \\
\hline Markies & Netherlands & Mid-late & Smooth \\
\hline Melody & Netherlands & Mid-early & Smooth \\
\hline Monalisa & Netherlands & Mid-early & Smooth \\
\hline Naturella & France & Mid-late & Smooth \\
\hline Opaline & France & Mid-early & Smooth \\
\hline Soléia & France & Mid-season & Smooth \\
\hline
\end{tabular}

${ }^{a}$ The foliage maturity type was based on the number of days from planting until maturity. Early $\leq 90$ days; mid-early = 91-100 days; mid-season $=101-110$ days; mid-late $=111-120$ days; late $\geq 121$ days. 
H.S.S. Duarte et al.

TABLE 2 - Origin, foliage maturity and skin type of the potato cultivars evaluated in experiment 3.

\begin{tabular}{|c|c|c|c|}
\hline Cultivar & Origin & Maturity $^{\mathrm{a}}$ & Skin type \\
\hline Ambra & Netherlands & Early & Smooth \\
\hline Amorosa & Netherlands & Mid-early & Smooth \\
\hline Annabelle & Netherlands & Early & Smooth \\
\hline Aracy Ruiva & Brazil & Late & Rough \\
\hline Armada & Netherlands & Mid-early & Mid-rough \\
\hline BRS Eliza & Brazil & Mid-season & Smooth \\
\hline Canelle & France & Mid-early & Smooth \\
\hline Catucha (resistant standard) & Brazil & Mid-season & Smooth \\
\hline Elodie (susceptible standard) & France & Mid-early & Smooth \\
\hline Fabula & Netherlands & Mid-season & Smooth \\
\hline Gredine & France & Mid-early & Smooth \\
\hline IPR Cris & Brazil & Mid-late & Rough \\
\hline Innovator & Netherlands & Mid-early & Rough \\
\hline Itararé & Brazil & Mid-late & Mid-rough \\
\hline Madeleine & Netherlands & Mid-early & Smooth \\
\hline Maranca & Netherlands & Mid-season & Mid-rough \\
\hline Marlen & Netherlands & Mid-season & Mid-rough \\
\hline Matador & Netherlands & Mid-early & Smooth \\
\hline Mozart & Netherlands & Mid-season & Smooth \\
\hline Rodeo & Netherlands & Mid-season & Mid-rough \\
\hline Sinora & Netherlands & Mid-early & Mid-rough \\
\hline Victoria & Netherlands & Mid-late & Rough \\
\hline Vivaldi & Netherlands & Mid-early & Smooth \\
\hline Voyager & Netherlands & Early & Smooth \\
\hline
\end{tabular}

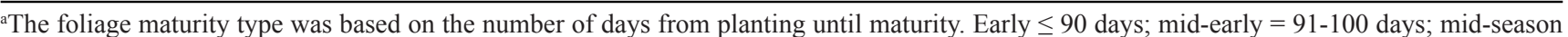
$=101-110$ days; mid-late $=111-120$ days; late $\geq 121$ days .

average and minimum temperature) were obtained from a meteorological station located in the experimental area.

\section{Inoculation and assessment of EB severity}

Potato plants in each plot were artificially inoculated with a mixture of eight isolates of $A$. grandis collected from different potato growing regions in Minas Gerais state (200 $\mathrm{mL}$ of a conidial suspension containing $10^{3}$ conidia $/ \mathrm{mL}$ ) at 31 days after planting. After inoculation, dimetomorph was applied as needed to control late blight using a backpack sprayer (conical tip with a pressure of $2.1 \times 10^{5} \mathrm{~Pa}$ at a rate of $600 \mathrm{~L} / \mathrm{ha}$ ). The severity of EB on all leaves of five plants per plot was quantified every seven days, beginning at inoculation, using a standard area diagram as described by Duarte et al. (2013). EB progress curves from cultivars exhibiting the same level of resistance were grouped to generate a unique progress curve for resistant, moderately resistant, moderately susceptible and susceptible groups.

\section{Data analysis}

\section{Experiment 1}

EB severity data from each cultivar were used to obtain four epidemiological variables. The first variable was severity in the middle of the epidemic $\left(\mathrm{Y}_{50}\right)$. The duration of an epidemic was defined as time from the onset of the first EB symptoms until all plants reached $100 \%$ severity (totally burned leaves). The second variable was the area under the disease progress curve (AUDPC) as described by Shaner \& Finney (1977). The AUDPC was divided by duration of the epidemic in days and multiplied by 100 to obtain relative area under the disease progress curve (RAUDPC), as proposed by Fry (1978). The third variable was time (in days) from the onset of the first EB symptoms until severity reached $0.5 \%\left(\mathrm{~T}_{05}\right)$. For any given each cultivar, $T_{05}$ was obtained from the onset of the first EB symptoms among all tested cultivars until the cultivar in question reached $0.5 \%$ severity. Finally, the fourth variable was the rate of disease progress $(r)$. Using the disease severity progress data, the exponential, monomolecular, Gompertz and logistic models were fitted with non-linear regressions based on Madden et al. (2007). The model with the lowest residual mean square, independence and homogeneity of errors as well as the highest coefficient of determination was selected as the best model.

Means of the four epidemiological variables, averaged from the three replications, were used in cluster, discriminant and principal component analyses to group the cultivars into resistance classes.

For cluster analysis, four epidemiological variables were used simultaneously to determine the level of resistance of each cultivar. The standardized Euclidean distance was used as a measure of dissimilarity, and the following agglomerative hierarchic techniques were utilized: single linkage, complete linkage, average linkage, centroid and 
Field resistance of potato cultivars to foliar early blight and its relationship with foliage...

ward (Johnson \& Wichern, 2007). The agglomerative hierarchic technique that best fit the data was chosen through visual analysis of the grouping pattern. To obtain the dendrogram, four groups were defined based on the level of resistance; these included resistant, moderately resistant, moderately susceptible and susceptible. Discriminant analysis was used to confirm the quality of the groupings formed using the agglomerative hierarchic technique to increase the reliability of the groupings.

Principal component analysis (PCA) was performed using data from a correlation matrix, and the estimated eigenvectors and eigenvalues were obtained for each principal component (PC). The scores from each of the 26 potato cultivars were estimated through eigenvectors for PCs presenting eigenvalues greater than the overall mean, according to the method of Kaiser (1958). Based on the results from Exp. 1, a method based on four epidemiological variables was used to determine the level of resistance of the potato cultivars used in Exps. 2 and 3. The PC1 scores were obtained from PCA. To ensure that the scores had the same sign (standardized value), the PC1 scores of each cultivar were added to the value with the opposite sign from the PC1 score of the most resistant cultivar. Therefore, the cultivars with the lowest (zero) and absolute highest standardized values were considered to be resistant and susceptible standards, respectively. After standardization, the response of each cultivar relative to its standardized value was obtained by dividing the standardized value of that cultivar by the standardized value for the most susceptible cultivar and multiplying by 100 . After obtaining the percentage values, a value range for each resistance level was determined.

\section{Experiments 2 and 3}

The PC1 scores from Exps. 2 and 3 were obtained based on the same epidemiological variables used to determine the EB resistance levels of the potato cultivars in Exp. 1. The standardized value of each cultivar was obtained based on cv. Catucha (resistant standard), and the percentage corresponding to the standardized value of each cultivar was obtained by comparing to the susceptible standard (cv. Elodie) as defined in Exp. 1. According to the values obtained, each cultivar was classified according to its EB resistance level based on the value range defined in Exp. 1. Next, the averages of the epidemiological variables of the cultivars were obtained within each resistance level.

Determination of the relationship between EB resistance of potato cultivars, their foliage maturity and tuber skin types

The EB resistance of the tested cultivars in the three different experiments based on their foliage maturity and tuber skin types was determined by graphical analysis and the chi-square test of independence $(P=0.05)$.

Statistical analyses were carried out with SAS version 9.1 (SAS Institute) and MINITAB version 14.

\section{RESULTS}

\section{Meteorological data}

For Exp. 1 the temperature ranged from 8.7 to $31.5^{\circ} \mathrm{C}$, with an average of $18.2^{\circ} \mathrm{C}$. Average relative humidity was $77.4 \%$, and the total rainfall was $33.4 \mathrm{~mm}$ (Figure 1A). For Exps. 2 and 3 the temperature ranged from 4.9 to $29.2^{\circ} \mathrm{C}$, with an average of $16.2^{\circ} \mathrm{C}$. Average relative humidity was $87.2 \%$, and the total rainfall was $23.7 \mathrm{~mm}$ (Figure 1B). The relative humidity ranged from 26 to $100 \%$ for Exp. 1 and from 36 to $100 \%$ for Exps. 2 and 3 (data not shown).

\section{Progress of EB}

Symptoms of EB were first noticed at 38 days after planting (dap) (first assessment) regardless of the experiment. At 87, 94 and 94 dap, cv. Catucha showed 100\% EB severity in Exps. 1, 2 and 3, respectively. The epidemic duration (time from the onset of the first EB symptoms until all plants reached $100 \%$ severity) was 50, 57 and 57 days, respectively, for Exps. 1, 2 and 3. The non-linear regression logistic model best fit the EB severity data for all cultivars regardless of the experiment.

\section{Levels of EB resistance among the potato cultivars}

\section{Experiment 1}

Based on the standardized Euclidean distance and the complete linkage method, the cultivars were grouped into four EB resistance levels with $100 \%$ hit rate. The percentages of resistant, moderately resistant, moderately susceptible and susceptible cultivars were 15.4, 7.7, 34.6 and $42.3 \%$, respectively. Cultivars Ibituaçu, Catucha, BRS Ana and Aracy were classified as resistant; Colorado and Baraka cvs. were classified as moderately resistant; Asterix, Atlantic, Caesar, Chipie, Florice, Markies, Monalisa, Naturella and Soléia were classified as moderately susceptible; and Ágata, Baronesa, Cupido, Éden, Elodie, Emeraude, Eole, Fontane, Gourmandine, Melody and Opaline were classified as susceptible (Figure 2). The foliar early blight progression curves related to each resistance level are represented in Figure 3A. The average of the eigenvalues obtained from all PCs was 1.0. Therefore, only PC1 was interpreted because it was the only one that presented an eigenvalue higher than the average. PC1 explained 83.0\% of the total data variation. As the resistance to EB increased, the $T_{05}$ values tended to increase (Table 3 ). Values for $\mathrm{Y}_{50}$, RAUDPC and $r$ tended to decrease as the level of EB resistance increased. A ranking for the response of the cultivars to $\mathrm{EB}$ was obtained based on the PC1 score estimations for the four epidemiological variables and on the percentage corresponding to the standardized value for each cultivar. The level of EB resistance in each cultivar decreased as the percentage values increased (Table 4). Cultivars Catucha and Elodie were considered to be the resistant and susceptible standards, respectively (Table 4). Based on the data from the four epidemiological variables 


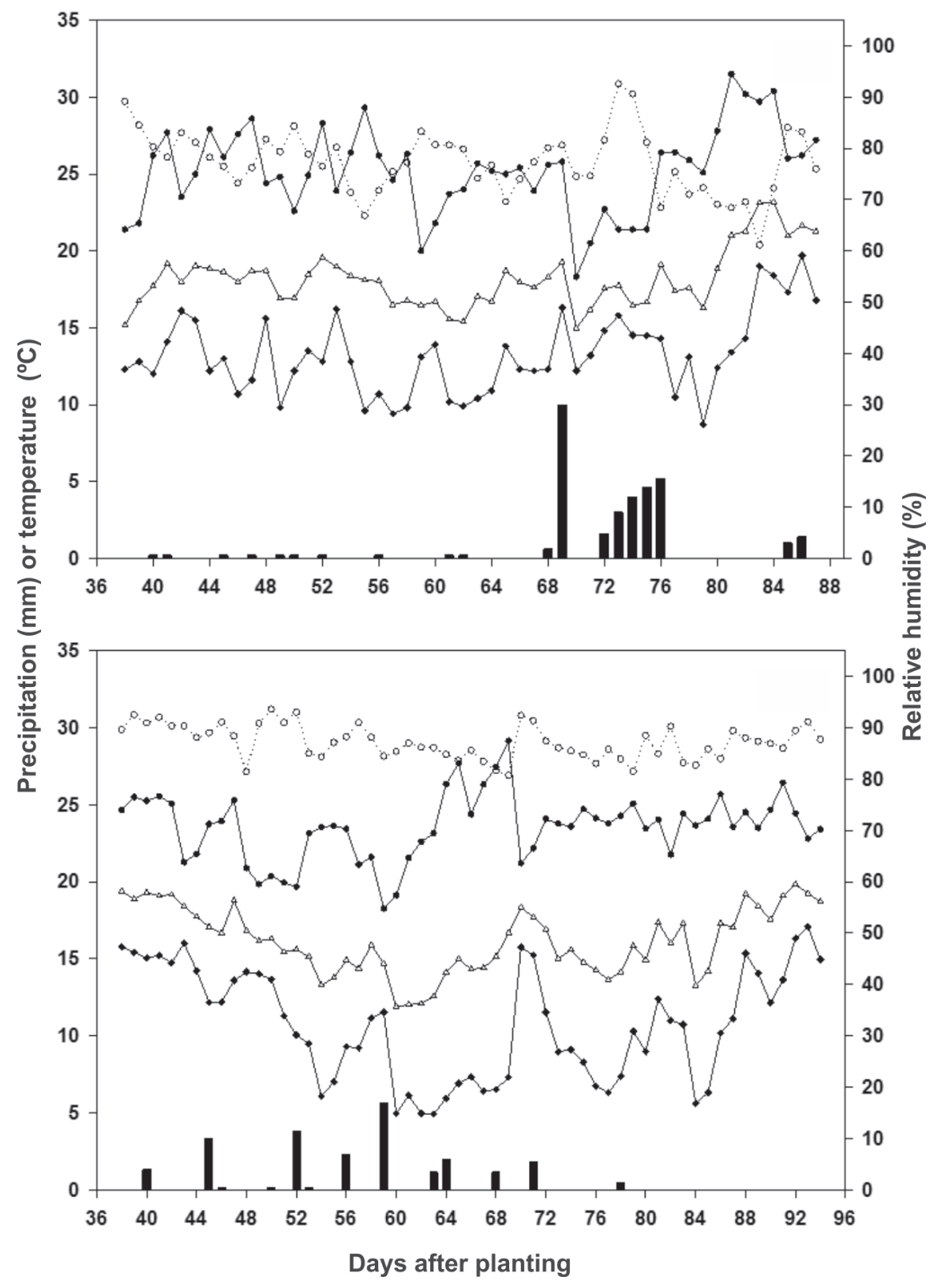

FIGURE 1 - Meteorological variables during the epidemics in experiments 1 (A), 2 and 3 (B). Relative humidity is represented by a dotted line with empty circles, pluviometric precipitation is represented by vertical bars and temperature is represented by a solid line. Maximum, medium and minimum temperatures are represented by the symbols $\rightarrow-\leftarrow$, and $\leftarrow$, respectively. and on the percentage of the standardized values of a certain cultivar in relation to the standardized value for cv. Elodie, a range for each level of EB resistance was obtained. The cultivars used in Exps. 2 and 3 with percentage values between 0.00 and 24.99 are considered as resistant, between 25.00 and 54.99 as moderately resistant, between 55.00 and 79.99 as moderately susceptible and greater than 80.00 as susceptible (Table 4).

\section{Experiments 2 and 3}

Regardless of the experiment, the average of the eigenvalues obtained from all PCs was 1.0; therefore, only PC1 was interpreted because it was the only one that presented an eigenvalue higher than the average. For Exps. 2 and 3,
PC1 explained 84.4 and $82.8 \%$ of the total data variation, respectively. The PC scores were obtained with data from the four epidemiological variables for each cultivar. Based on the percentage of the standardized values of a certain cultivar in relation to the standardized values of cv. Elodie and on the range of the values defined in Exp. 1, in Exp. 2, Ibituaçu, Catucha, BRS Ana and Aracy were classified as resistant; Asterix, Atlantic, Baraka, Colorado, Florice, Markies, Monalisa and Naturella were classified as moderately resistant; Caesar, Chipie, Éden, Emeraude, Eole, Fontane, Gourmandine and Soléia were classified as moderately susceptible; and Ágata, Baronesa, Cupido, Elodie, Melody and Opaline were classified as susceptible (Table 5). The percentages of resistant, moderately resistant, 


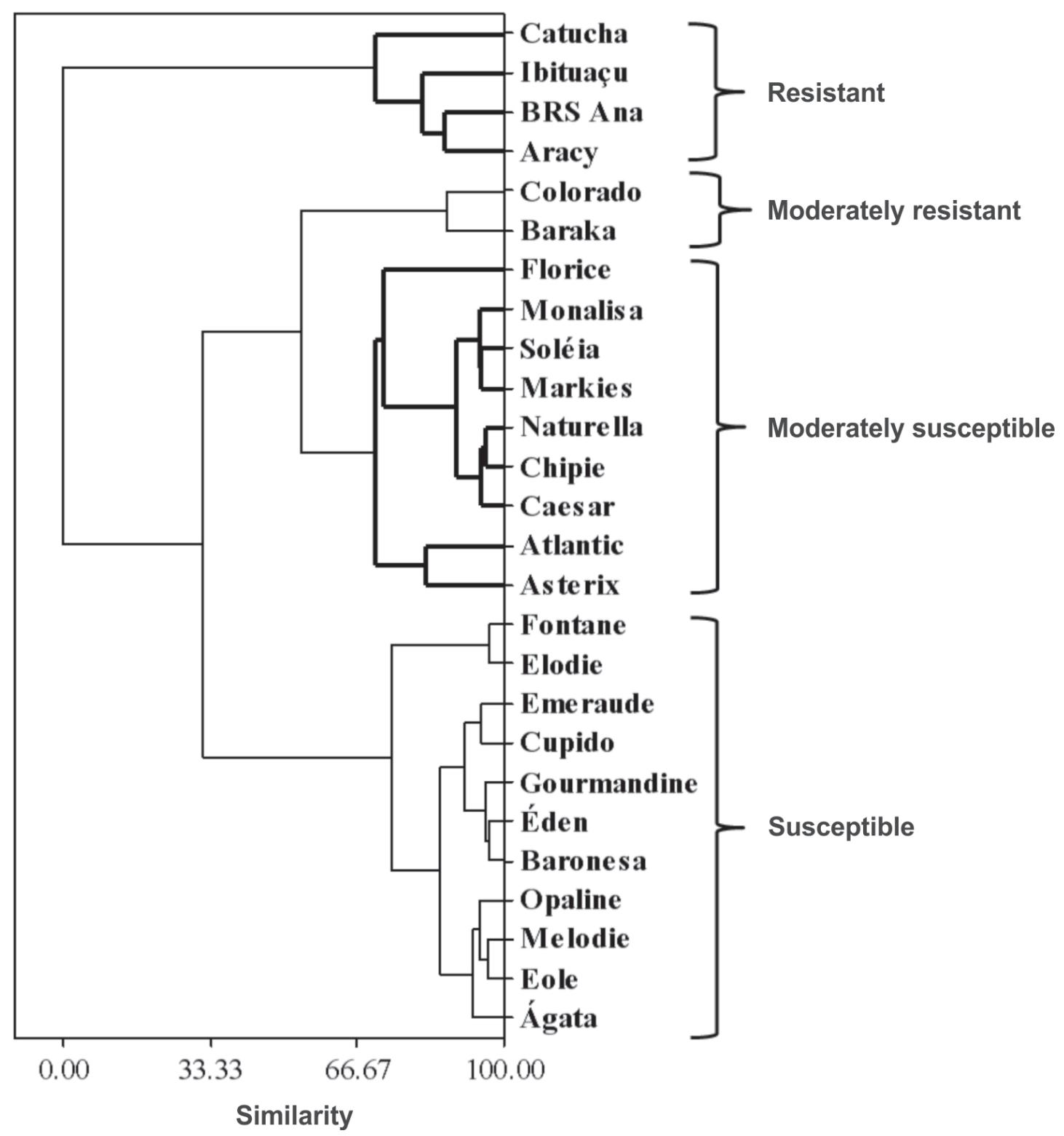

FIGURE 2 - Dendrogram for the potato cultivars clustered according to their levels of early blight resistance based on the standardized Euclidean distance and on the complete linkage method.

moderately susceptible and susceptible were 15.4, 30.8, 30.8 and $23.0 \%$, respectively. The foliar early blight progression curves related to each resistance level are represented in Figure 3B. For Exp. 3, Aracy Ruiva, Catucha and Itararé were classified as resistant; Amorosa, Annabelle, Armada, BRS Eliza, Fabula, IPR Cris, Maranca and Mozart were classified as moderately resistant; Innovator, Madeleine, Matador, Rodeo, Sinora and Victoria were classified as moderately susceptible; and Ambra, Canelle, Elodie, Gredine, Marlen, Vivaldi and Voyager cultivars were classified as susceptible (Table 5). The percentages of resistant, moderately resistant, moderately susceptible and susceptible cultivars were 12.5 , $33.3,25.0$ and $29.2 \%$, respectively. The foliar early blight progression curves related to each resistance level are represented in Figure 3C. Regardless of the experiment, the resistance of a certain cultivar decreased as the percentage of the standardized values increased (Table 5). With PC1 score estimations of all four epidemiological variables and the percentage of the standardized value of each cultivar, a ranking of the cultivars was obtained, which allowed for the identification of cultivars that were more resistant or more susceptible to EB.

Relationship between EB resistance of the potato cultivars and their foliage maturity type

The EB-resistant cultivars were mid-season, midlate or late maturity (Figure 4). None of the EB-susceptible cultivars were later maturity (mid-late or late maturity). 


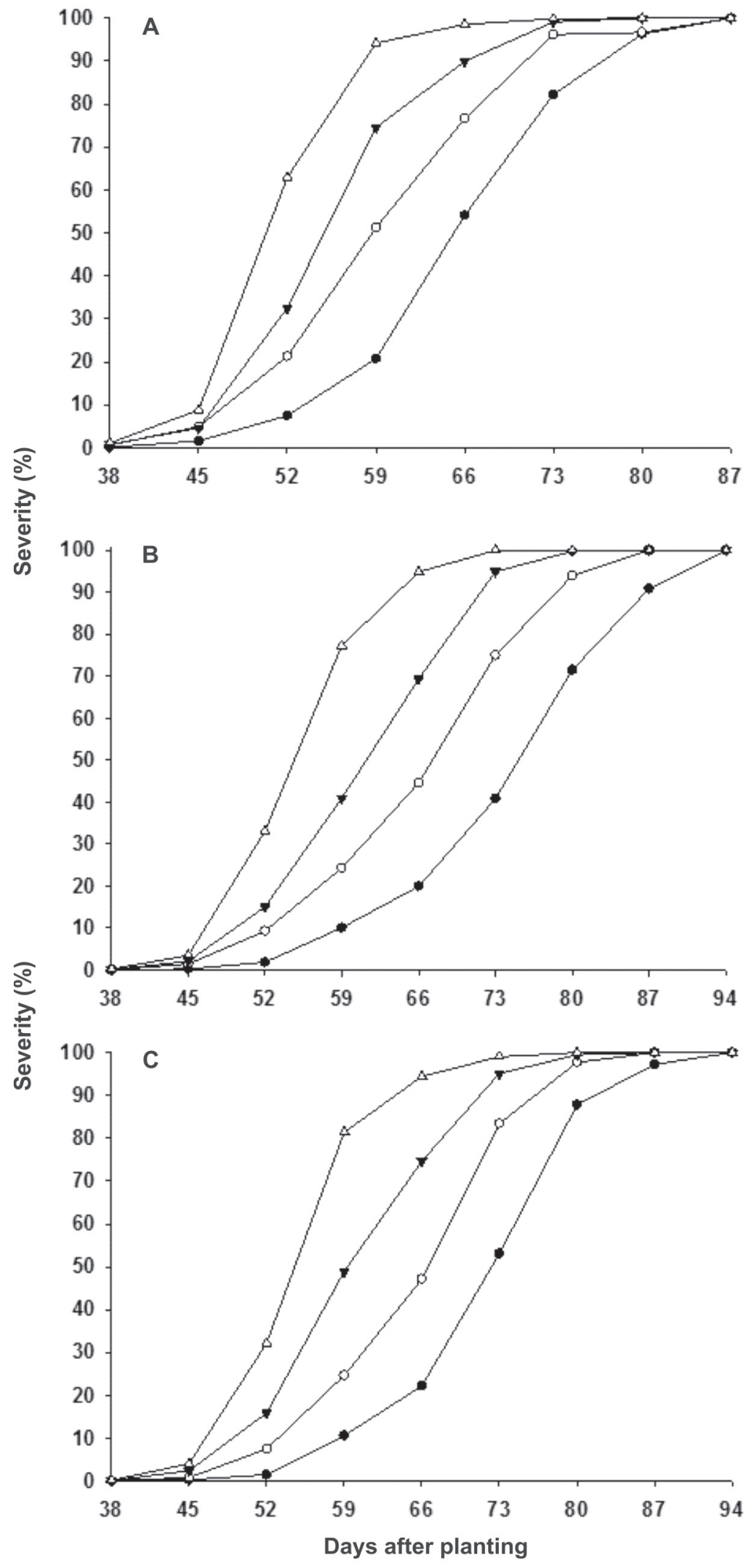

FIGURE 3 - Progress curves of potato cultivars at each level of early blight resistance evaluated in experiments 1 (a), 2 (b) and 3 (c). The resistant, moderately resistant, moderately susceptible and susceptible groups are represented by the symbols $\longrightarrow,-\infty,-$ and $-\backsim$, respectively. 
Field resistance of potato cultivars to foliar early blight and its relationship with foliage...

TABLE 3 - Mean relative area under disease progress curve (RAUDPC), severity in the middle of the epidemic ( $\left.{ }_{50}\right)$, rate of disease progress $(r)$ and time in days from the onset of the first symptoms until of $0.5 \%$ severity $\left(\mathrm{T}_{0.5}\right)$ for the four levels of resistance evaluated on experiments 1,2 and 3 .

\begin{tabular}{|c|c|c|c|c|}
\hline \multirow[t]{3}{*}{ Resistance levels $^{\mathrm{a}}$} & \multicolumn{4}{|c|}{ Variables } \\
\hline & RAUDPC & $Y_{50}$ & $r$ & $\mathbf{T}_{0.5}$ \\
\hline & \multicolumn{4}{|c|}{ Exp. 1} \\
\hline $\mathrm{R}$ & 0.45 & 35.06 & 0.20 & 5.60 \\
\hline MR & 0.53 & 53.09 & 0.22 & 2.71 \\
\hline MS & 0.66 & 83.35 & 0.34 & 1.60 \\
\hline \multirow[t]{2}{*}{$\mathrm{S}$} & 0.74 & 96.05 & 0.46 & 1.12 \\
\hline & \multicolumn{4}{|c|}{ Exp. 2} \\
\hline $\mathrm{R}$ & 0.35 & 19.98 & 0.17 & 10.58 \\
\hline MR & 0.50 & 48.96 & 0.20 & 3.53 \\
\hline MS & 0.58 & 64.69 & 0.22 & 2.69 \\
\hline \multirow[t]{2}{*}{ S } & 0.70 & 95.21 & 0.30 & 1.50 \\
\hline & \multicolumn{4}{|c|}{ Exp. 3} \\
\hline $\mathrm{R}$ & 0.39 & 22.21 & 0.21 & 10.45 \\
\hline MR & 0.50 & 47.14 & 0.22 & 6.19 \\
\hline MS & 0.60 & 74.65 & 0.24 & 3.39 \\
\hline $\mathrm{S}$ & 0.69 & 94.40 & 0.33 & 1.97 \\
\hline
\end{tabular}

${ }^{\mathrm{a}} \mathrm{R}=$ resistant; $\mathrm{MR}=$ moderately resistant; $\mathrm{MS}=$ moderately susceptible; $\mathrm{S}=$ susceptible.

TABLE 4 - Resistance levels, principal component 1 (PC1) scores obtained from the four epidemiological variables, standardized values, percentages of the standardized values for each cultivar in relation to the standardized value of cv. Elodie and ranges for each early blight resistance level for the potato cultivars evaluated in experiment 1.

\begin{tabular}{|c|c|c|c|c|c|}
\hline Cultivars & Resistance level $^{\mathrm{a}}$ & Score $\mathbf{P C 1}{ }^{\mathrm{b}}$ & Standardized value & $\%^{\mathrm{c}}$ & Range \\
\hline Catucha & $\mathrm{R}$ & 4.64 & 0.00 & 0.00 & $0.00-24.99$ \\
\hline Aracy & & 3.40 & -1.25 & 18.18 & \\
\hline BRS Ana & & 3.28 & -1.36 & 19.81 & \\
\hline Ibituaçu & & 3.07 & -1.58 & 22.96 & \\
\hline Colorado & MR & 1.64 & -3.01 & 43.85 & $25.00-54.99$ \\
\hline Baraka & & 0.97 & -3.67 & 53.53 & \\
\hline Asterix & MS & 0.78 & -3.86 & 56.29 & $55.00-79.99$ \\
\hline Florice & & 0.17 & -4.48 & 65.25 & \\
\hline Caesar & & 0.07 & -4.57 & 66.62 & \\
\hline Chipie & & -0.19 & -4.83 & 70.44 & \\
\hline Atlantic & & -0.21 & -4.85 & 70.71 & \\
\hline Naturella & & -0.22 & -4.87 & 70.96 & \\
\hline Monalisa & & -0.41 & -5.05 & 73.63 & \\
\hline Soléia & & -0.53 & -5.17 & 75.36 & \\
\hline Markies & & -0.65 & -5.29 & 77.20 & \\
\hline Emeraude & S & -0.86 & -5.50 & 80.25 & $>80.00$ \\
\hline Cupido & & -1.01 & -5.65 & 82.35 & \\
\hline Gourmandine & & -1.14 & -5.78 & 84.28 & \\
\hline Baronesa & & -1.23 & -5.87 & 85.62 & \\
\hline Éden & & -1.30 & -5.95 & 86.71 & \\
\hline Ágata & & -1.41 & -6.05 & 88.22 & \\
\hline Eole & & -1.42 & -6.06 & 88.41 & \\
\hline Melody & & -1.49 & -6.13 & 89.44 & \\
\hline Opaline & & -1.71 & -6.35 & 92.57 & \\
\hline Fontane & & -2.03 & -6.67 & 97.30 & \\
\hline Elodie & & -2.22 & -6.86 & 100.00 & \\
\hline
\end{tabular}

${ }^{\mathrm{a}} \mathrm{R}=$ resistant; $\mathrm{MR}=$ moderately resistant; $\mathrm{MS}=$ moderately susceptible; $\mathrm{S}=$ susceptible.

${ }^{\mathrm{b}}$ The PC1 scores were obtained from the four selected epidemiological variables.

'Percentages of standardized values of the cultivars in relation to the standardized values of cv. Elodie. 
H.S.S. Duarte et al.

TABLE 5 - Principal component 1 (PC1) scores obtained for the four epidemiological variables, percentages of standardized values for each cultivar in relation to the standardized values of cv. Elodie and the early blight resistance levels from experiments 1,2 and 3.

\begin{tabular}{|c|c|c|c|c|c|c|c|c|}
\hline Cultivars & $\begin{array}{c}\text { Resistance } \\
\text { Exp. 1 }^{\mathrm{a}} \\
\end{array}$ & $\begin{array}{c}\text { PC1 } \\
\text { Exp. } 2^{b} \\
\end{array}$ & $\%^{c}$ & $\begin{array}{c}\text { Resistance } \\
\text { Exp. 2 }\end{array}$ & Cultivars & $\begin{array}{c}\text { PC1 } \\
\text { Exp. } 3^{b} \\
\end{array}$ & $\%^{c}$ & $\begin{array}{c}\text { Resistance } \\
\text { Exp. } 3^{\text {a }} \\
\end{array}$ \\
\hline Ágata & $\mathrm{S}$ & -2.81 & 98.03 & $\mathrm{~S}$ & Ambra & -1.65 & 82.98 & $\mathrm{~S}$ \\
\hline Aracy & $\mathrm{R}$ & 2.61 & 17.52 & $\mathrm{R}$ & Amorosa & 0.99 & 42.44 & MR \\
\hline Asterix & MS & 1.63 & 32.14 & MR & Annabelle & 1.22 & 38.99 & MR \\
\hline Atlantic & MS & 0.75 & 45.16 & MR & Aracy Ruiva & 2.24 & 23.31 & $\mathrm{R}$ \\
\hline Baraka & MR & 0.51 & 48.76 & MR & Armada & 1.21 & 39.15 & MR \\
\hline Baronesa & $\mathrm{S}$ & -1.74 & 82.07 & $\mathrm{~S}$ & BRS Eliza & 1.53 & 34.30 & MR \\
\hline BRS Ana & $\mathrm{R}$ & 2.87 & 13.74 & $\mathrm{R}$ & Canelle & -2.44 & 94.93 & $\mathrm{~S}$ \\
\hline Caesar & MS & -0.24 & 59.91 & MS & Catucha & 3.77 & 0.00 & $\mathrm{R}$ \\
\hline Catucha & $\mathrm{R}$ & 3.79 & 0.00 & $\mathrm{R}$ & Elodie & -2.77 & 100.00 & $\mathrm{~S}$ \\
\hline Chipie & MS & -0.61 & 65.28 & MS & Fabula & 1.32 & 37.41 & MR \\
\hline Colorado & MR & 1.33 & 36.48 & MR & Gredine & -2.09 & 89.70 & $\mathrm{~S}$ \\
\hline Cupido & $\mathrm{S}$ & -1.82 & 83.29 & $\mathrm{~S}$ & IPR Cris & 0.92 & 43.59 & MR \\
\hline Éden & $\mathrm{S}$ & -0.93 & 70.04 & MS & Innovator & -0.29 & 62.10 & MS \\
\hline Elodie & $\mathrm{S}$ & -2.94 & 100.00 & $\mathrm{~S}$ & Itararé & 2.69 & 16.54 & $\mathrm{R}$ \\
\hline Emeraude & $\mathrm{S}$ & -0.68 & 66.43 & MS & Madeleine & -0.31 & 62.43 & MS \\
\hline Eole & $\mathrm{S}$ & -0.11 & 57.89 & MS & Maranca & 1.63 & 32.73 & MR \\
\hline Florice & MS & 1.24 & 37.93 & MR & Marlen & -1.84 & 85.77 & $\mathrm{~S}$ \\
\hline Fontane & $\mathrm{S}$ & -0.46 & 63.10 & MS & Matador & -0.98 & 72.73 & MS \\
\hline Gourmandine & $\mathrm{S}$ & -0.66 & 66.06 & MS & Mozart & 0.41 & 51.31 & MR \\
\hline Ibituaçu & $\mathrm{R}$ & 2.61 & 17.52 & $\mathrm{R}$ & Rodeo & -0.39 & 63.56 & MS \\
\hline Markies & MS & 0.10 & 54.74 & MR & Sinora & -0.43 & 64.18 & MS \\
\hline Melody & $\mathrm{S}$ & -2.08 & 87.24 & $\mathrm{~S}$ & Victoria & 0.11 & 55.99 & MS \\
\hline Monalisa & MS & -1.20 & 74.05 & MR & Vivaldi & -3.02 & 103.80 & $\mathrm{~S}$ \\
\hline Naturella & MS & 1.69 & 31.12 & MR & Voyager & -1.84 & 85.82 & S \\
\hline Opaline & $\mathrm{S}$ & -2.73 & 96.75 & $\mathrm{~S}$ & - & - & - & - \\
\hline Soléia & MS & -0.12 & 58.05 & MS & - & - & - & - \\
\hline
\end{tabular}

${ }^{\mathrm{a}} \mathrm{R}=$ resistant; $\mathrm{MR}=$ moderately resistant; $\mathrm{MS}=$ moderately susceptible; $\mathrm{S}=$ susceptible.

${ }^{b}$ The PC1 scores were obtained for the four epidemiological variables.

'Percentages of standardized values of the cultivars in relation to the standardized values of cv. Elodie.

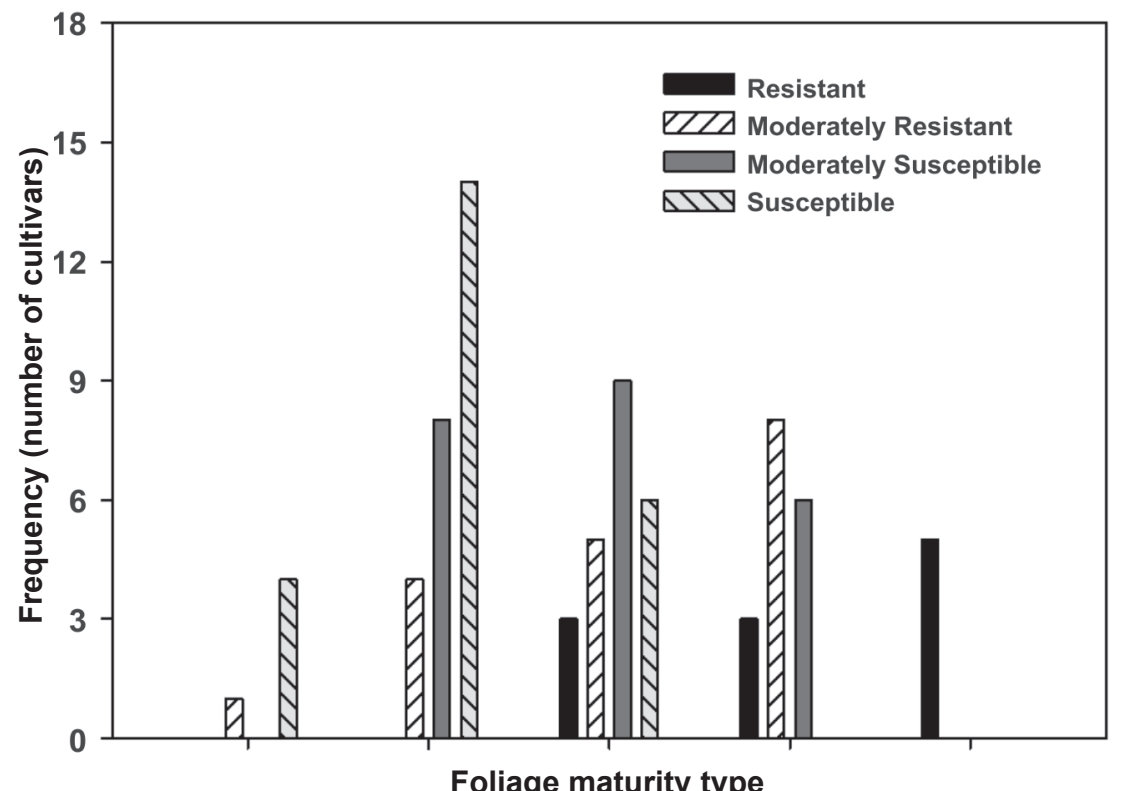

Foliage maturity type
FIGURE 4 - Frequency of four levels of resistance of the potato cultivars to early blight according to their foliage maturity types. The data shown are from experiments 1,2 and 3. 
In most cases, the cultivars that were susceptible to EB were earlier maturity (early or mid-early maturity). The relationship between the level of resistance to EB and the foliage maturity type was confirmed by the chi-square test of independence $(P<0.001)$

\section{Relationship between EB resistance of the potato cultivars and their skin type}

The cultivars that were most resistant to EB had rough, mid-rough or smooth skin. None of the EB-susceptible cultivars had rough skin (Figure 5). In most cases, the cultivars that were susceptible or moderately susceptible to EB had smooth skin. The relationship between the level of EB resistance and the skin type was confirmed by the chisquare test of independence $(P=0.012)$.

\section{DISCUSSION}

To the best of our knowledge, the current study presents the first data on the level of resistance among several potato cultivars to EB under different weather conditions in Brazil. Furthermore, a novel approach to classify the resistance of potato cultivars to EB was based on a standardized method, which offered the following advantages: (a) it allows for the classification of cultivars or genotypes according to their EB resistance via comparisons with known cultivars (a resistant and a susceptible standard); (b) the use of multivariate analysis techniques avoids overlapping classifications that often result from standard multiple comparisons tests and that make it difficult to separate cultivars or genotypes according to their levels of EB resistance; (c) the PCA technique is useful for determining the resistance levels and ranking the cultivars based on their level of resistance or susceptibility to EB; and (d) a more comprehensive and simplified interpretation of the EB resistance of potato cultivars is achieved through the simultaneous analysis of four important epidemiological variables with multivariate techniques.

Previous field evaluations of EB resistance of potato cultivars have used only one or a few epidemiological variables, such as disease severity at any given time during the epidemic (Brune \& Reifschneider, 1989; Brune et al., 1990; Christ, 1991; Reifschneider \& Brune, 1992; Brune et al., 1994), the AUDPC (Christ, 1991; Dita-Rodríguez et al., 2006; Simon et al., 2009) and $r$ (Holley et al., 1983). Nazareno et al. (1999) suggested that caution must be taken if only one epidemiological variable is used during disease assessment. For example, the exclusive use of the AUDPC or $r$ may cause problems with data interpretation. Progress curves resulting in the same values for AUDPC may be accompanied by differences in the initial time of occurrence of the epidemic, the final disease severity and the $r$ values. Moreover, similar $r$ values may be accompanied by differences in the AUDPC. Christ (1991) ranked potato cultivars based on their EB resistance with separate analyses of single epidemiological variables: disease severity at a given time during the epidemic and AUDPC. Different rankings of EB resistance for the potato cultivars tested resulted from these separate analyses of the two epidemiological variables.

For the standardized method developed in the present study to classify the potato cultivars resistance to $\mathrm{EB}$, the cvs. Catucha and Elodie were used as the resistant and the susceptible standards, respectively. Future studies aiming to determine the level of resistance of other cultivars to $\mathrm{EB}$ at different locations in Brazil should include cvs. Catucha and Elodie. After obtaining the percentages of standardized values for the tested cultivars in relation to the standardized value for $\mathrm{cv}$. Elodie, it is necessary to

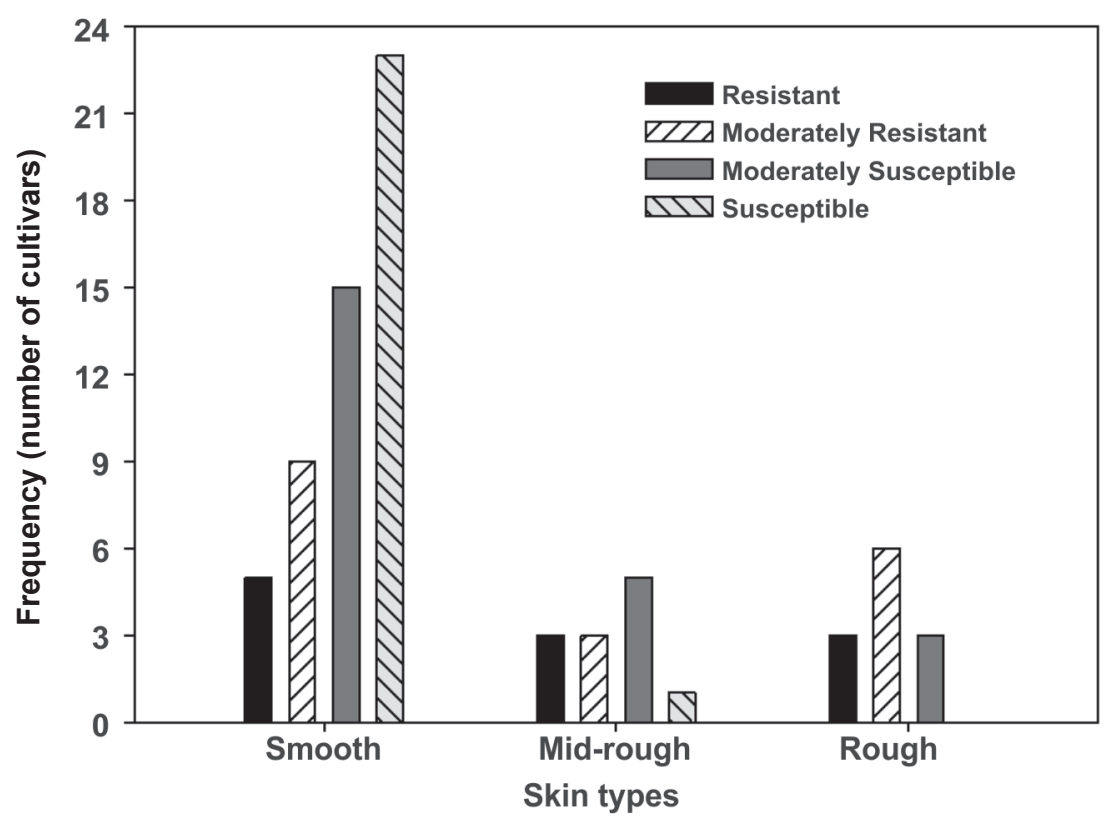

FIGURE 5 - Frequency of four levels of resistance of the potato cultivars to early blight according to their skin types. The data shown are from experiments 1,2 and 3. 
verify the range for each EB resistance level for the tested cultivars. One example can be obtaind in the Exp. 3, for which the cultivars used were different from those used in Exps. 1 and 2, without excluding the cvs. Catucha and Elodie, ensuring that the standard classification of the cultivars was based on their levels of resistance to EB. To determine the level of cultivar resistance to EB in other countries, it is recommended that the procedures used in the present study should be followed to determine specific resistant and susceptible standards.

In potato, EB resistance trait exhibits quantitative inheritance (Herriott et al., 1990; Christ \& Haynes, 2001), Therefore, potato genotypes with race-specific resistance to EB are difficult to obtain (Zachmann, 1982). In the present study, none of the tested cultivar showed vertical resistance to EB. EB occurred due to favorable weather conditions and the availability of pathogen inoculum, and the severity of the disease was dependent on the resistance level of each cultivar. Considering that the resistance level of potato cultivars is quite variable under field conditions (Douglas \& Pavek, 1972), it is meaningful to define intermediate levels of resistance. Therefore, categories such as "moderately resistant" and "moderately susceptible" prove to be very useful in practice if the simple dichotomy of resistant and susceptible is not sufficient. The potato cultivars showed quantitative resistance to EB because disease progress was reduced over time based on the $r$ values.

The relationship between EB progress and plant maturity is a very well documented phenomenon. In general, earlier cultivars are more susceptible to EB, whereas later cultivars are more resistant (Harrison et al., 1965; Douglas \& Pavek, 1972; Rich, 1983; Brune et al., 1990; Herriott et al., 1990; Christ, 1991; Zhang, 2004), and this was confirmed in the present study. Of the five cultivars classified as resistant to EB, only cv. Catucha was not midlate or late maturing. This cultivar was considered to be the resistant standard and exhibited mid-season maturity. These findings show that the later-maturing cultivars are not necessarily more resistant to EB compared to the cultivars exhibiting mid-season maturity, which is in agreement with the results obtained by Christ (1991). The cv. Elodie, considered the susceptible standard, exhibited a mid-early maturity. Earlier maturing potato genotypes with field resistance to EB have been identified (Herriott et al., 1990; Reifschneider\& Brune 1992; Boiteux et al., 1995; Simon et al., 2009). The identification of such cultivars is important because breeding programs aim to obtain earlier maturity cultivars with higher levels of resistance to EB (Brune \& Reifschneider, 1989; Brune et al., 1990; Reifschneider \& Brune, 1992; Brune et al., 1994).

Another feature associated with potato resistance to EB is plant age, and younger plants are usually more resistant than older plants (Johnson \& Theng, 1990; DitaRodríguez et al., 2006). It is known that potato susceptibility to EB gradually increases from the initiation of tuberization (Bussey \& Stevenson, 1991; Pscheidt \& Stevenson, 1988).
The same cultivars and pathogen isolates were used in Exps. 1 and 2. Some cultivars exhibited higher levels of resistance to EB in Exp. 2 than in Exp. 1, mainly because of the favorable environmental conditions for EB progress in Exp. 1, which contributed to a shortened epidemic and higher $r$ values. According to Van der Plank (1963), the level of resistance of a certain potato cultivar to foliar diseases is directly related to the environmental conditions, which is one of the major characteristics of quantitative resistance in a hostpathogen interaction.

In general, the skin of the most susceptible (i.e., susceptible and moderately susceptible) cultivars was smoother than skin of most resitant cultivars (i.e., moderately resistant and resistant). For example, cvs. Ágata and Cupido are widely cultivated due to their attractiveness to consumers, although they are classified as susceptible to EB. It is more plausible that the cultivars were selected in environments where EB was not important, or that during the selection of potato cultivars with desirable characteristics such as high yield, clear and smooth skin and shallow eyes, the genes involved in potato resistance to EB were lost. The skin type of the potato tuber is of extreme importance for in natura consumption because smooth-skinned tubers are preferred in the markets. However, tubers with rougher skins would be suitable for industrial processing.

Most of the cultivars assessed in the present study and that showed to be more resistant to EB (R and MR) are considered old cultivars, but for some reasons (longcycle maturity, low yield, skin type and inadequate tuber shape for trade and lack of potato tubers in the market) are no longer cultivated or have no potential to be used by the farmers. In this case, even though these cultivars do not have any commercial use, they can be a good source of genetic resistance against EB. Growers can choose comercial cultivars with greater resistance levels to EB to reduce the production costs, enhancing competitiveness at the markets and enabling the entire potato production chain to become more sustainable.

\section{ACKNOWLEDGEMENTS}

The authors thank Eduardo S. G. Mizubuti for providing the isolates of $A$. grandis used in this study. This study was supported by grants from Coordenação de Aperfeiçoamento de Pessoal de Nível Superior - CAPES, Conselho Nacional de Desenvolvimento Científico e Tecnológico - CNPq and Fundação de Amparo à Pesquisa do Estado de Minas Gerais - FAPEMIG. F.A.R. and L.Z. thank CNPq for their fellowship. H.S.S.D. was supported by CNPq and CAPES.

\section{REFERENCES}

Adams SS, Stevenson WR (1990) Water management, disease development and potato production. American Journal of Potato Research 67:3-11. 
Field resistance of potato cultivars to foliar early blight and its relationship with foliage...

Batista DC, Lima MA, Haddad F, Maffia LA, Mizubuti ESG (2006) Validation of decision support systems for tomato early blight and potato late blight, under Brazilian conditions. Crop Protection 25:664-670.

Boiteux LS, Reifschneider, FJB, Fonseca MEN, Buso JA (1995) Search for sources of early blight (Alternaria solani) field resistance not associated with vegetative late maturity in tetraploid potato germplasm. Euphytica 83:63-70.

Brune S, Melo PE, Lima MF (1994) Resistência a Alternaria solani, características agronômicas e qualidade de fritura em clones de batata imunes a PVY e PVX. Horticultura Brasileira 12:125-130.

Brune S, Reifschneider FJB (1989) Avaliação da resistência de batata à pinta-preta. Horticultura Brasileira 7:20-21.

Brune S, Reifschneider FJB (1992) Identificação de fontes de resistência à pinta-preta em batata. Horticultura Brasileira 10:100-102.

Brune S, Reifschneider FJB, Buso JA (1990) Resistência de genótipos de batata (Solanum tuberosum) à pinta-preta (Alternaria solani). Fitopatologia Brasileira 15:297-299.

Bussey MJ, Stevenson WR (1991) A leaf disk assay for detecting resitance to early blight caused by Alternaria solani in juvenile potato plants. Plant Disease 75:385-390.

Castro MEA, Zambolim L, Chaves GM, Cruz CD, Matsuoka K (2000) Variabilidade patogênica de Alternaria solani, agente causal da pinta-preta do tomateiro. Summa Phytopathologica $8: 24-28$.

Christ BJ (1991) Effect of disease assessment method on ranking cultivars for resistance to early blight. Plant Disease 75:353-356.

Christ BJ, Haynes KG (2001) Inheritance of resistance to early blight disease in a diploid potato population. Plant Breeding 120:169-172.

Dita-Rodríguez MA, Brommonschenkel SH, Matsuoka K, Mizubuti ESG (2006) Components of resistance to early blight in four potato cultivars: effect of leaf position. Journal of Phytopathology 154:230-235.

Douglas DR, Pavek JJ (1972) Screening potatoes for field resistance to early blight. American Journal of Potato Research 49:1-6.

Duarte HSS, Zambolim L, Capucho AS, Nogueira Junior, AF, Rosado AWC, Cardoso CR, Paul PA, Mizubuti ESG (2013) Development and validation of a set of standard area diagrams to estimate severity of potato early blight. European Journal of Plant Pathology 137:249-257.

FAO (2014) FAOStat. Available at: faostat.fao.org/site/567/ DesktopDefault.aspx? PageID $=567$ \#ancor. Accessed on Feb 07,2014

Fry WE (1978) Quantification of general resistance of potato cultivars and fungicide effects for integrated control of potato late blight. Phytopathology 68:1650-1655.

Guenthner JF, Wiese MV, Pavlista AD, Sieczka JB, Wyman J (1999) Assessment of pesticide use in the US potato industry. American Journal of Potato Research 76:25-29.

Harrison MO, Livingston CH, Oshima M (1965) Epidemiology of potato early blight in Colorado. 1. Initial infection, disease development and the influence of environmental factors. American Journal of Potato Research 42:279-291.

Herriott AB, Haynes Jr FL, Shoemaker PB (1990) Inheritance of resistance to early blight disease in tetraploid $\mathrm{x}$ diploid crosses of potatoes. Hortscience 25:224-226.

Holley JE, Hall R, Hofstra G (1983) Identification of ratereducing resistance to early blight in potato. Canadian Journal Plant Pathology 5:111-114.

Johnson KB, Teng PS (1990) Coupling a disease progress model for early blight to a model of potato growth. Phytopathology $80: 416-425$.

Johnson RA, Wichern DW (2007) Applied Multivariate Statistical Analysis. Upper Saddle River, NJ. USA. Prentice Hall.

Jones JB, Stall RE, Zitter TA (1991) Compendium of Tomato Diseases. St. Paul, MN, USA. APS Press.

Kaiser HF (1958) The varimax criterion for analytic rotation in factor analysis. Psychometrika 23:187-200.

Madden LV, Hughes G, Van Den Bosh F (2007) The Study of Plant Disease Epidemics. St. Paul, MN, USA. APS Press.

Mendoza HA, Martin C, Vallejo RL, Espinoza J (1986) Breeding resistance to early blight (Alternaria solani). American Potato Journal 63:444-445.

Nazareno NRX, Scotti CA, Mafioletti, RL, Boschetto N (1999) Controle da requeima da batata através do monitoramento das variáveis climáticas. Fitopatologia Brasileira 24:170-174.

Pelletier JR, Fry WE (1990) Characterization of resistance to early blight in three potato cultivars: receptivity. Phytopathology 80:511-517.

Pscheidt JW, Stevenson WR (1986) Comparison of forecasting methods for control of potato early blight in Wiscosin. Plant Disease 70:361-366.

Reifschneider FJB, Furumoto O, Filgueira FAR (1984) Illustrated key for the evaluation of early blight of potatoes. Plant Protection Bulletin 32:91-94.

Rich AE (1983) Potato Diseases. New York, NY, USA. Academic Press.

Rodrigues TTMS, Berbee ML, Simmons EG, Cardoso CR, Reis A, Maffia LA, Mizubuti ESG (2010) First report of Alternaria tomatophila and $A$. grandis causing early blight on tomato and potato in Brazil. New Disease Reports 22:28-28.

Rotem J (1994) The genus Alternaria: biology, epidemiology and pathogenicity. St Paul, MN, USA. APS Press.

Shaner G, Finney RE (1977) The effect of nitrogen fertilization on the expression of slow-mildewing resistance in knox wheat. Phytopathology 67:1051-1056.

Shuman JL, Christ BJ (2005) Integrating a host-resistance factor into the fast system to forecast early blight of potato. American Journal of Potato Research 82:9-19.

Simmons EG (2000) Alternaria themes and variations (244286). Species on Solanaceae. Mycotaxon 75:1-115.

Simon AG, Pinto CABP, Lambert ES, Andreu MA (2009) Seleção de clones de batata resistentes à pinta preta e tolerantes ao calor. Revista Ceres 56:31-37.

Van Der Plank JE (1963) Plant Disease: Epidemics and Control. 
H.S.S. Duarte et al.

St. Paul, MN, USA. APS Press.

Zachmann R (1982) Early blight of potato (Alternaria solani). Technical Information Bulletin. Lima, Peru. CIP.
Zhang R (2004) Genetic characterization and mapping of partial resistance to early blight in diploid potato. Ph.D. Thesis, The Pennsylvania State University. University Park, PA, USA. 